\title{
Karakterisasi Asap Cair Hasil Pirolisis Sampah Kantong Plastik sebagai Bahan Bakar Bensin
}

\section{Dewe K. Anom*, John Z. Lombok}

Kimia, FMIPA, Universitas Negeri Manado, Tondano, 95619, Indonesia

\begin{tabular}{l} 
I N F O A R T I K E L \\
\hline Diterima 29 September 2020 \\
Disetujui 26 Oktober 2020 \\
\\
\hline Key word: \\
plastic waste, \\
pyrolysis, \\
characterization, \\
liquid smoke, \\
gasoline \\
\hline Kata kunci: \\
sampah plastik, \\
pirolisis, \\
karakterisasi, \\
asap cair, \\
bensin \\
\hline
\end{tabular}

${ }^{*} e$-mail:

dewaanom10@gmail.com

\begin{abstract}
A B S T RACT
Plastic bag waste is garbage that is difficult to degrade in nature. Hoarding plastic bag waste can reduce soil fertility because it cannot be broken down by microorganisms quickly. Burning plastic bag waste can produce toxic gases and have a negative impact on human health and the environment. To solve the problem, the plastic bag waste is converted into liquid smoke as fuel oil. The method used to convert the plastic bag waste into liquid smoke is pyrolysis. The fractionation of liquid smoke at temperatures below $200^{\circ} \mathrm{C}$ produces $36.20 \%$ clear liquid which has similar properties to gasoline fuel. Characterization of the physical and chemical properties of the gasoline fraction liquid smoke has a density of $0.76 \mathrm{~g} / \mathrm{mL}$; a viscosity of $0.80 \mathrm{cP}$; boiling point at $146.9^{\circ} \mathrm{C}$; flash point at $30.60^{\circ} \mathrm{C}$; a calorific value of $10,520 \mathrm{cal} / \mathrm{g}$; with the octane number of 98 RON. GC-MS analysis shows that the gasoline fraction liquid smoke consists of 45 chemical compounds which can be classified into alkanes, alkenes, cycloalkanes and alcohols.
\end{abstract}

\section{A B STRAK}

Sampah kantong plastik adalah sampah yang sulit terdegradasi di alam. Penimbunan sampah kantong plastik dapat menurunkan kesuburan tanah karena tidak dapat terurai oleh mikroorganisme dengan cepat. Pembakaran sampah kantong plastik dapat menghasilkan gas-gas-gas beracun dan berdampak bagi kesehatan manusia dan lingkungan. Untuk mengatasi permasalahan khusus sampah kantong plastik maka sampah kantong plastik dikonversi menjadi asap cair sebagai bahan bakar minyak. Metode yang digunakan untuk mengubah sampah kantong plastik menjadi asap cair adalah pirolisis. Fraksinasi asap cair pada suhu di bawah 200oC menghasilkan 36,20\% cairan bening yang sifat-sifatnya mirip dengan bahan bakar bensin. Karakterisasi sifat fisika dan kimia asap cair fraksi bensin mempunyai massa jenis 0,76 gr/mL, viskositas $0,80 \mathrm{cP}$; titik didih 146,9oC; titik nyala 30,60oC; nilai kalor 10.520 kal./gr; bilangan oktan 98 RON. Analisis GC-MS menunjukkan bahwa asap cair fraksi bensin terdiri dari 45 senyawa kimia yang dapat digolongkan ke dalam alkana, alkena, sikloalkana dan alkohol.

\section{Pendahuluan}

Seiring dengan bertambahnya jumlah penduduk dunia, konsumsi akan barangbarang plastik semakin meningkat. Kota-kota besar di Indonesia banyak mengalami masalah perkotaan, seperti banjir, kemacetan dan masalah sampah. Sampah merupakan salah satu masalah yang cukup memprihatinkan bagi perkotaan yang sebagian besar penduduknya dengan gaya hidup konsumtif sehingga sampah yang dihasilkan cukup tinggi [1]. Sampah anorganik seperti kantong plastik, botol plastik, tabung plastik, pipa plastik, dan styrofoam adalah sampah yang tidak mudah terurai oleh mikroorganisme di dalam tanah dan air. Sampah plastik yang ada pada saat ini hanya dibuang, dibakar atau didaur ulang. Proses tersebut belum menyesesaikan semua 
permasalahan sampah plastik. Apabila sampah plastik dibakar akan menghasilkan senyawa berbahaya yang bersifat karsinogenik seperti polychloro dibenzodioxins dan polychloro dibenzo furan. Daur ulang limbah plastik merupakan satu-satunya cara yang dapat mengurangi jumlah sampah plastik, tetapi hasil daur ulang mempunyai kualitas rendah dan hasilnya sedikit sehingga metode daur ulang dianggap tidak efisien untuk memecahkan masalah sampah plastik [2].

Plastik merupakan bahan anorganik buatan yang tersusun dari bahan-bahan kimia yang cukup berahaya bagi lingkungan [3]. Plastik yang beredar di pasaran saat ini merupakan polimer sintetik yang terbuat dari minyak bumi [4]. Plastik adalah polimer rantai panjang dari atom yang mengikat satu sama lain. Plastik adalah salah satu jenis makromolekul yang dibentuk dengan proses polimerisasi. Plastik merupakan senyawa polimer yang unsur penyusun utamanya adalah karbon dan hidrogen. Untuk membuat plastik, salah satu bahan baku yang sering digunakan adalah naphta, yaitu bahan yang dihasilkan dari penyulingan minyak bumi atau gas alam [5]. Sampah plastik digolongkan dalam sampah yang tidak dapat didegradasi, karena sampah jenis ini membutuhkan waktu yang relatif sangat lama untuk dapat didegradasi oleh alam [6].

Sampah plastik sangat potensial mencemari lingkungan karena plastik merupakan bahan yang sulit terdegradasi sehingga jika ditimbun dalam penimbunan akhir akan memberikan banyak masalah [7]. Pembakaran sampah plastik kurang efektif dan beresiko sebab dengan pembakaran sampah plastik muncul polutan dari emisi gas buang; $\mathrm{CO}_{2}, \mathrm{CO}, \mathrm{NO}_{x}$ dan $\mathrm{SO}_{x}$, yang dapat mengganggu kesehatan [8].

Pirolisis adalah salah satu metode yang dapat digunakan untuk mengubah sampah plastik menjadi bahan bakar cair dan dapat diproses lebih lanjut menjadi bahan bakar minyak yang sama dengan bahan bakar bensin. Keuntungan menerapkan metode pirolisis antara lain memiliki rasio konversi yang tinggi dan produknya mempunyai kandungan energi yang tinggi pula. Pirolisis didefinisikan sebagai degradasi termal dari bahan bakar padat pada kondisi udara/oksigen terbatas dimana proses ini akan menghasilkan gas, tar dan char [9].

Dalam pembuatan bahan bakar alternatif ada beberapa hal yang harus diperhatikan yaitu: titik nyala ataupun titik bakar terjadi pada temperatur yang cukup rendah, dan nilai kalor bensin cukup tinggi berkisar antara 10.160-11.000 kkal/kg [10]. Pokok-pokok mengenai energi telah dicantumkan dalam kebijakan Energi Nasional yang bertujuan untuk menghemat bahan bakar minyak bumi dan pengembangan sumber-sumber energi alternatif lainnya. Salah satu energi alternatif yang sekarang dikembangkan adalah energi yang berasal dari bahan-bahan organik, hal ini dikarenakan senyawa organik tersebut tergolong energi yang dapat diperbaharui. Salah satunya yaitu berupa sampah organik yang jumlahnya dari waktu ke waktu semakin bertambah [11].

Sampah plastik akan berdampak negatif terhadap lingkungan karena tidak dapat terurai dengan cepat dan dapat menurunkan kesuburan tanah [5]. Semakin bertambah pesat penggunaan plastik maka semakin banyak pula limbah yang akan kita hadapi, baik itu yang dihasilkan dari industri besar maupun industri rumah tangga. Limbah plastik menjadi permasalahan lingkungan yang sampai saat ini belum dapat dipecahkan jalan keluarnya meskipun banyak pemanfaatan limbah plastik namun belum mampu mengurangi penumpukan sampah plastik di alam [12]. Plastik adalah polimer yang sulit dapat terdegradasi di alam dan plastik mengandung unsur karbon, hidrogen dan unsur lainnya yaitu klorin dan nitrogen [13]. Karena sifatnya yang tidak dapat terdegradasi, senyawa ini berkontribusi secara signifikan terhadap masalah pengolahan limbah plastik.

Pengolahan sampah plastik khususnya sampak kantong plastik untuk dikonversi menjadi bahan bakar minyak sangat menarik untuk dikembangkan. Jika sampah plastik yang jumlahnya cukup besar ini dapat diolah menjadi bahan bakar bensin maka hal ini menjadi solusi yang tepat untuk memecahkan permasalahan sampah plastik.

\section{Bahan dan Metode}

Sampah yang digunakan dalam penelitian 
ini adalah sampah kantong plastik yang di ambil dari lokasi pembuangan sampah akhir (TPA) desa Sumompo Kota Manado. Alat-alat yang digunakan dalam penelitian ini adalah satu set alat pirolisis, 1 set alat destilasi fraksinasi, kondensor, gelas erlemeyer, corong pisah, gelas ukur, timbangan analitik, penjepit, tandar, pisau, pipet, thermometer, fenske viscometer oswald, smoke point tester, picnometer, flash point meter, boilling point meter, frezer point tester dan satu set alat perpaduan KG-SM, 1 set alat Bomb Calorimeter dan 1 set alat OKTVIC-2.

Langkah-langkah penelitian pirolisis sampah kantong mengikuti prosedur penelitian yang dilakukan sebelumnya [14-17]. Sampah kantong plastik yang digunakan sebagai sampel penelitian dikumpulkan dari tempat pembuangan sampah, kemudian dicuci sampai bersih dan dijemur sampai kering dan dipotong-potong hingga berukuran $3-4 \mathrm{~cm}$. Sampah plastik kemudian ditimbang sampai $200 \mathrm{~g}$ dan setelah itu sampel tersebut dimasukan ke dalam alat pirolisis. Perubahan suhu pirolisis dan perubahan-perubahan fisik yang terjadi seperti sampah plastik mulai meleleh, mencair, dan menguap diamati selama proses. Uap yang diperoleh didinginkan dan cairan hasil pendinginan ditampung dalam Erlenmeyer. Proses pirolisis sampah kantong plastik dihentikan apabila tidak ada lagi pirolisat yang menetes ke dalam Erlenmeyer.

Pirolisat adalah asap cair yang merupakan campuran hidrokarbon. Selanjutnya pirolisat yang didapat diperlakukan distilasi fraksinasi dengan tujuan untuk memisahkankomponen asap cair pada suhu $\leq 200^{\circ} \mathrm{C}$. Asap cair hasil fraksinasi diberi kode A1. Asap cair A1 dikarakterisasi berdasarkan sifat fisika dan kimia yaitu : massa jenis, viskositas, titik didih, titik nyala, kalor pembakaran, bilangan oktan, GC-MS.

\section{Hasil dan Pembahasan}

Pirolisis Sampah Kantong Plastik.

Proses pirolisis sampah kantong plastik berlangsung selama kurang lebih 3 sampai 4 jam. Pengamatan pirolisis sampah kantong plastik adalah sebagai berikut:
1. Pirolisis pada suhu $110-120^{\circ} \mathrm{C}$, dapat teramati bahwa sampah kantong plastik secara perlahan-lahan mulai meleleh. Di samping itu juga dapat teramati adanya gelembung-gelembung udara dan asap putih yang cukup banyak di dalam labu pirolisis.

2. Pirolisis pada suhu $140-160^{\circ} \mathrm{C}$, teramati bahwa sampah kantong plastik mulai mencair kemudian mendidih dan menguap. Pada tahapan ini asap putih dalam labu pirolisis sudah hilang.

3. Pirolisis pada suhu $160-200^{\circ} \mathrm{C}$, terlihat adanya titik-titik embun yang menempel pada dinding kondensor. Beberapa menit kemudian teramati adanya cairan mulai menetes, dan cairan tersebut ditampung dalam gelas Erlenmeyer.

4. Pirolisis pada suhu sekitar $200-275^{\circ} \mathrm{C}$, terlihat kecepatan cairan plastik menetes mulai stabil.

5. Proses pirolisis berakhir sampai tidak ada lagi distilat yang menetes dan waktu yang digunakan kurang lebih 4 jam.

6. Dari pirolisis $200 \mathrm{~g}$ sampah kantong plastik diperoleh pirolisat asap cair sebanyak 164,00 g.

Selanjutnya asap cair yang didapat diperlakukan distilasi fraksinasi yang bertujuan untuk memisahkan bahan bakar bensin dari campurannya. Menurut Koesoemadinata (1980) bahwa distilasi fraksinasi bahan bakar bensin berada pada titik didih $<200^{\circ} \mathrm{C}$. Dari $164,00 \mathrm{~g}$ asap cair yang didapat dan setelah perlakukan fraksinasi menghasilkan kurang lebih 72,40 g fraksi bensin atau 36,20\% fraksi bensin dari 200 g sampah plastik [18].

Asap cair dari sampah kantong plastik fraksi bensin yang diperoleh berwarna jernih, sedangkan warna bahan bakar bensin yang beredar dipasaran berwarna kuning pucat. Perbedaan warna ini dapat disebabkan karena penyusun senyawa-senyawa kimia dari ke dua bahan bakar tersebut tidak sama. Di samping itu juga proses pembuatan asap cair dari sampah plastik fraksi bensin melalui proses pirolisis dan distilasi fraksinasi, sedangkan bahan bakar bnesin dari minyak bumi diproses secara langsung melalui distilasi bertingkat. Karakteristik asap cair dari sampah kantong plastik fraksi bensin ditunjukkan pada Tabel 1. 
Tabel 1. Karakteristik Asap Cair dari Sampah Kantong Plastik Fraksi Bensin

\begin{tabular}{|l|c|c|}
\hline Karakteristik & $\begin{array}{c}\text { Hasil } \\
\text { Penelitian }\end{array}$ & $\begin{array}{c}\text { Bensin } \\
\text { (SNI) }\end{array}$ \\
\hline $\begin{array}{l}\text { Massa Jenis } \\
(\mathrm{gr} / \mathrm{mL})\end{array}$ & 0,76 & $0,71-0,77$ \\
\hline Viskositas $(\mathrm{cP})$ & 0,80 & 0,70 \\
\hline Titik Didih $\left({ }^{\circ} \mathrm{C}\right)$ & 146,9 & $40-180$ \\
\hline $\begin{array}{l}\text { Titik Nyala } \\
\left({ }^{\circ} \mathrm{C}\right)\end{array}$ & 30,60 & - \\
\hline $\begin{array}{l}\text { Nilai Kalor } \\
(\text { kal./gr }\end{array}$ & 11.027 & $11.414,453$ \\
\hline $\begin{array}{l}\text { Bilangan } \\
\text { Oktan (RON) }\end{array}$ & 98 & $86-94$ \\
\hline $\begin{array}{l}\text { Jumlah } \\
\text { Senyawa (GC- } \\
\text { MS) }\end{array}$ & 45 & - \\
\hline
\end{tabular}

Massa Jenis

Dari Tabel 1 dapat diketahui bahwa massa jenis asap cair dari kantong plastik fraksi bensin sebesar $0,76 \mathrm{gr} / \mathrm{mL}$. Niali yang dihasilkan ini berada diantara standart mutu bensin yang perbolehkan oleh Standard Nasional Indonesia (SNI) yaitu 0,71-0,77 gr/mL [19]. Pada umumnya massa jenis bahan bakar harus memiliki nilai densitas yang rendah karena apabila nilai densitas bahan bakar terlalu tinggi maka akan meningkatkan keausan mesin dan menyebabkan kerusakan pada mesin [20].

\section{Viskositas}

Viskositas asap cair dari kantong plastik fraksi bensin adalah sebesar $0,80 \mathrm{cP}$ (tabel 1). Nilai viskositas ini mendekati nilai viskositas yang disarankan oleh SNI yaitu $0,70 \mathrm{cP}$, dan standar mutu internasional yang dikeluarkan oleh Shell Petroleum Canada tahun 1999 bahwa nilai viskositas yang diperbolehkan untuk bahan bakar jenis bensin adalah $<1$ cSt [21].

\section{Titik Didih}

Dari tabel 1 diketahui bahwa titik didih asap cair dari kantong plastik fraksi bensin adalah $146,9^{\circ} \mathrm{C}$. Berdasarkan SNI 06-3506-1994 titik didih akhir bahan bakar yang diizinkan maksimal sebesar $205^{\circ} \mathrm{C}$ [21]. Pada penelitian ini titik didih asap cair hasil pirolisis menunjukkan angka di bawah batas maksimum standar mutu yang berlaku. Berdasarkan nilai titik didihnya maka asap cair tersebut dapat diusulkan sebagai bahan bakar alternatif pengganti bensin.

\section{Titik Nyala (flash point)}

Tabel 1 menunjukkan bahwa hasil pengujian titik nyala pada asap cair hasil pirolisis sampah kantong plastik fraksi bensin adalah sebesar $30,60^{\circ} \mathrm{C}$. Titik nyala bensin yang beredar dipasaran adalah sebesar $57^{\circ} \mathrm{C}$. Hasil tersebut menunjukkan angka di bawah titik nyala bensin yang beredar dipasaran, sehingga asap cair fraksi bensin dapat diusulkan sebagai bahan alternatif pengganti bensin. Titik nyala suatu bahan bakar menandakan batas aman terhadap bahaya kebakaran selama penyimpanan.

\section{Nilai Kalor}

Nilai kalor asap cair hasil pirolisis sampah katong plastik fraksi bensin adalah sebesar 10.520 kal./gr. Nilai kalor dari bahan bakar minyak pada umumnya berkisar antara 10.160$11.000 \mathrm{kkal} / \mathrm{kg}$ [10].

\section{Bilangan Oktan}

Bilangan oktan asap cair hasil pirolisis sampah katong plastik fraksi bensin adalah sebesar 98 RON. Menurut Standar dan Mutu (spesifikasi) bahan bakar minyak bensin yang di pasarkan di dalam negeri minimum $90 \mathrm{RON}$ [19]. Bensin premium dikatakan memiliki angka oktan 90 berarti bahwa bensin tersebut memiliki karakteristik ketukan dalam uji mesin uji standar CFT ASTM yang sama dengan karakteristik ketukan campuran antara $90 \%$ vol iso-oktan dalam campuran dengan n-heptan.

\section{Analisis GC-MS}

Berdasarkan analisis GC bahwa kromatogram asap cair hasil pirolisis sampah katong plastik fraksi bensin ditunjukkan pada Gambar 1. Kromatogram GC menunjukkan bahwa asap cair hasil pirolisis sampah katong plastik fraksi bensin terdiri dari 45 puncak atau 45 senyawa. Setelah dikelompokkan berdasarkan spektra MS ternyata asap cair hasil pirolisis sampah katong plastik fraksi bensin terdiri dari campuran senyawa hidrokarbon golongan alkana, alkena, sikloalkana dan alkohol. 


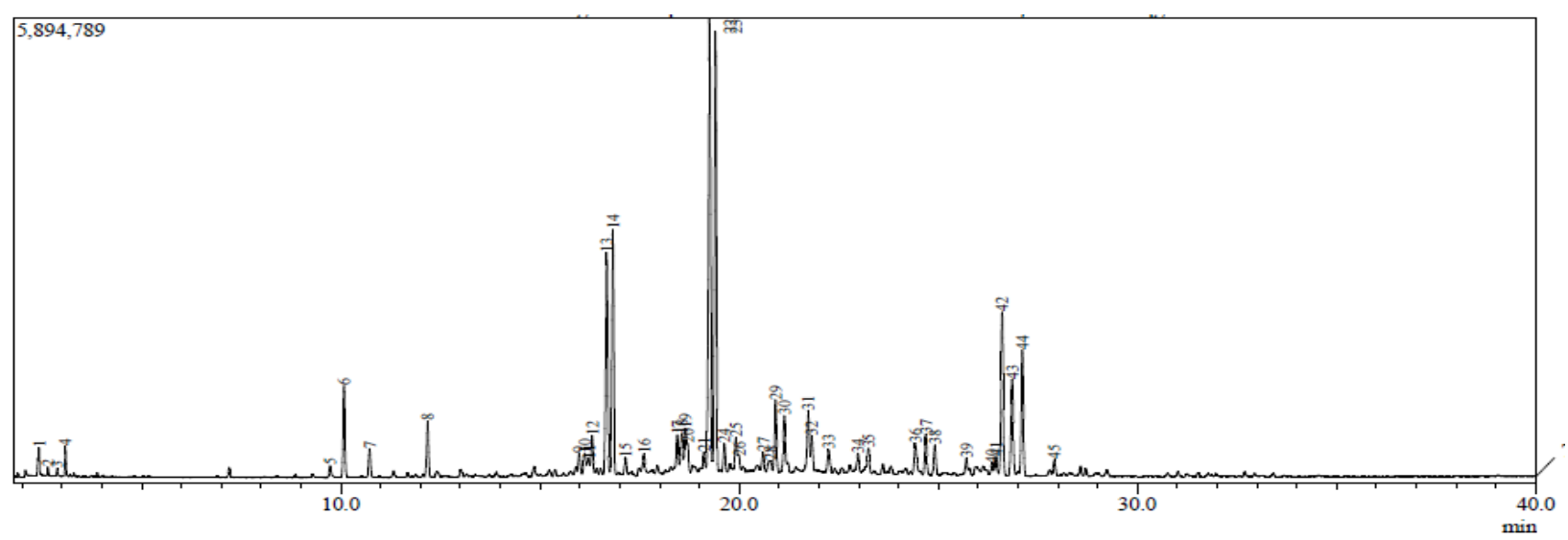

Gambar 1. Kromatogram GC asap cair hasil pirolisis sampah katong plastik fraksi bensin

\section{Kesimpulan}

Dari penelitian ini dapat disimpulkan bahwa pirolisis $200 \mathrm{~g}$ sampah kantong plastik menghasilkan asap cair fraksi bensin sebesar $36,20 \%$. Berdasarkan sifat fisika dan kimia maka asap cair dari sampah kantong plastik fraksi bensin dapat memenuhi spesifikasi bahan bakar bensin yang beredar dipasaran, tetapi belum dapat digunakan karena perlu adanya analisis mineral yang terkandung didalamnya. Analisis GC-MS menunjukkan bahwa asap cair fraksi bensin terdiri dari 45 senyawa kimia yang dapat digolongkan ke dalam alkana, alkena, sikloalkana dan alkohol.

\section{Daftar Pustaka}

1. Damanhuri, E. Indonesia Solid Waste Association (InSWA). 2013,.

2. Ermawati, R. Konversi limbah plastik sebagai sumber energi alternatif. Journal of Industrial Research (Jurnal Riset Industri) 2011, 5, 257-263.

3. Wahyono, E.H.; Sudarno, N. Pengelolaan Sampah Plastik: Aneka Kerajinan dari Sampah Plastik; Yapeka: Bogor, 2012;

4. Kadir, K. Kajian Pemanfaatan Sampah Plastik Sebagai Sumber Bahan Bakar cair. Dinamika: Jurnal Ilmiah Teknik Mesin 2012, 3.

5. Surono, U.B. Berbagai metode konversi sampah plastik menjadi bahan bakar minyak. Jurnal Teknik 2013, 3, 32-40.

6. Andarini, N.; Purwo, S.H.D. Konversi Plastik Menjadi Senyawa Fraksi Bahan Bakar Cair Melalui Reaksi Perengkahan Katalitik Dengan Katalis Ni (II)/H5NZA.
Saintifika 2009, 11, 171-180.

7. Sahwan, F.L. Sistem pengelolaan limbah plastik di Indonesia. Jurnal teknologi lingkungan 2005, 6 .

8. Sumarni, S.; Purwanti, A. Kinetika Reaksi Pirolisis Plastik Low Density Poliethylene (LDPE). Jurnal Teknologi 2008, 1, 135-140.

9. Di Blasi, C. Modeling chemical and physical processes of wood and biomass pyrolysis. Progress in energy and combustion science 2008, 34, 47-90.

10. Wiratmaja, I.G. Pengujian karakteristik fisika biogasoline sebagai bahan bakar alternatif pengganti bensin murni. Jurnal Ilmiah Teknik Mesin 2010, 4, 145-154.

11. Subroto, S.; Prastiyo, D. Unjuk Kerja Tungku Gasifikasi Dengan Bahan Bakar Sekam Padi Melalui Pengaturan Kecepatan Udara Pembakaran. Media Mesin: Majalah Teknik Mesin 2013, 14.

12. Anggono, T.; Wahyu, E.; Handayani, H.; Rahmadani, A.; Abdullah, A. Pirolisis Sampah Plastik untuk Mendapatkan Asap Cair dan Penentuan Komponen Kimia Penyusunnya Serta Uji Kemampuannya Sebagai Bahan Bakar Cair. Jurnal Sains dan Terapan Kimia 2016, 3, 164-173.

13. Maceiras, R. Diesel fuel from plastic waste. Pharm Anal Chem Open Access 2016, 2, e105.

14. Iswadi, D.; Nurisa, F.; Liastuti, E. Pemanfaatan Sampah Plastik LDPE Dan PET menjadi Bahan Bakar Minyak dengan Proses Pirolisis. Jurnal Ilmiah Teknik Kimia UNPAM 2017, 1.

15. Rekathakusuma, I.; Suwandi, S.; Suhendi, A. Karakterisasi Bahan Cair Produk Distilasi Sampah Plastik Dan 
Pemanfaatannya Sebagai Bahan Bakar. In Proceedings of the eProceedings of Engineering; 2016.

16. Anom, I.D.K.; Lombok, Z. Utilization of Bread Wrapper Plastic Waste as Alternative Energy of Gasoline Fuel. International Journal of Applied Chemistry 2016, 12, 375387.

17. Mogot, R.L.; Anom, D.; Kumajas, J. Destilasi Kering Sampah Plastik Low Density Polyethylene (LDPE). Fullerene Journal of Chemistry 2020, 5, 5-9.

18. Koesoemadinata, R.P. Geologi Minyak dan Gas Bumi; Institut Teknologi Bandung: Bandung, 1980;

19. Dirjen Migas Standar Mutu (Spesifikasi) Bahan Bakar Minyak Jenuis Bensin (Gasoline) RON 98 yang dipasarkan di Dalam Negeri; $\mathrm{p}$. 2018;

20. Setiawati, E.; Edwar, F. Teknologi pengolahan biodiesel dari minyak goreng bekas dengan teknik mikrofiltrasi dan transesterifikasi sebagai alternatif bahan bakar mesin diesel. Jurnal Riset Industri Online 1999, 6.

21. Badan Standar Nasional Mutu Bahan bakar minyak jenis bensin; Vol. 1. 75.160.20;

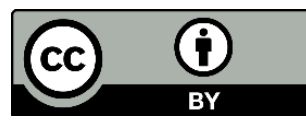

C 2020 by the authors. Licensee Fullerene Journal Of Chem. This article is an open access article distributed under the terms and conditions of the Creative Commons Attribution (CC BY) license

(http://creativecommons.org/licenses/by/4.0/). 